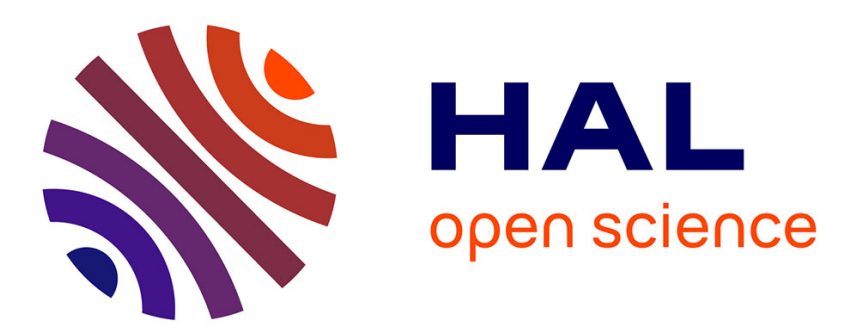

\title{
Quaternary glacial events in the Pyrenees from U-series dating of speleothems in the Niaux-Lombrives-Sabart caves, Ariège, France
}

\author{
Michel Bakalowicz, Patrick Sorriaux, Derek C. Ford
}

\section{To cite this version:}

Michel Bakalowicz, Patrick Sorriaux, Derek C. Ford. Quaternary glacial events in the Pyrenees from U-series dating of speleothems in the Niaux-Lombrives-Sabart caves, Ariège, France. Norsk Geografisk Tidsskrift / Norwegian Journal of Geography, 1984, 38 (3-4), 10.1080/00291958408552125 . hal01412828

\section{HAL Id: hal-01412828 \\ https://hal.science/hal-01412828}

Submitted on 13 Jun 2019

HAL is a multi-disciplinary open access archive for the deposit and dissemination of scientific research documents, whether they are published or not. The documents may come from teaching and research institutions in France or abroad, or from public or private research centers.
L'archive ouverte pluridisciplinaire HAL, est destinée au dépôt et à la diffusion de documents scientifiques de niveau recherche, publiés ou non, émanant des établissements d'enseignement et de recherche français ou étrangers, des laboratoires publics ou privés. 


\title{
Quaternary glacial events in the Pyrenees from U-series dating of speleothems in the Niaux-Lombrives-Sabart caves, Ariège, France
}

\author{
MICHEL BAKALOWICZ, PATRICK SORRIAUX \& DEREK C. FORD
}

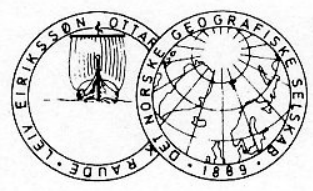

Bakalowicz, M., Sorriaux, P. \& Ford, D. C. 1984. Quaternary glacial events in the Pyrenees from Useries dating of speleothems in the Niaux-Lombrives-Sabart caves, Ariège, France. Norsk geogr. Tidsskr. Vol. 38, 193-197. Oslo. ISSN 0029-1951.

Located at approximately $150 \mathrm{~m}$ above the present base level, the caves of Niaux, Lombrives and Sabart are an old drainage system, which worked between the Vicdessos and Ariège Valleys. In these caves, three successive sedimentary units were studied in detail. Each unit consists of two parts: the lower deposit is detrital, of fluvial origin, and testifies to a hydrological working of the conduit system; the upper deposit of each unit is mostly speleothems, corresponding to a draining of the conduits as the paleokarst evolved above base level. This is similar to the present environment of the caves.

Only the speleothems from the upper part of each unit were dated by the ${ }^{230} \mathrm{Th} /{ }^{2.34} \mathrm{U}$ method. The dates, from 27 samples, are in good agreement with Europe and North America data. The data from the middle (250 to $200 \mathrm{ka} \mathrm{BP}$ ) and upper ( 90 to $20 \mathrm{ka} \mathrm{BP}$ ) fluvial sediments correspond to major glacial events, which re-activated the karst system.

Two further events resulted in a lack of carbonated sedimentation, the first between 350 and $290 \mathrm{ka}$ $\mathrm{BP}$, the second between 175 and $130 \mathrm{ka} \mathrm{BP}$. Comparing the data from other places, these two events can be related to glacial periods of minor importance in the study area, because of the lack of erosion and of detrital sediments.

The oldest detrital sediments are covered by speleothems older than $350 \mathrm{ka}$ BP and, partly, older than $720 \mathrm{ka} \mathrm{BP}$ (from paleomagnetic data to be confirmed); from sedimentary data, they may not be related to a glacial event. They are perhaps contemporary with the area's initial cave formation.

Michel Bakalowicz, Laboratoire Souterrain du CNRS, Moulis, Saint-Girons, France.

Patrick Sorriaux, Societé Nationale Elf-Aquitaine, SNEA (P), 65 Pau, France.

Derek C. Ford, Department of Geography, McMaster University, Hamilton, Ontario L8S 4KI, Canada.

The Niaux, Lombrives and Sabart cave system is developed in Jurassic and Cretaceous limestones forming a local massif, Cap de la Lesse, that lies between the confluence of two rivers, the Ariège and the Vicdessos, $20 \mathrm{~km}$ south of Foix in the Ariège district of the Pyrenees. The caves are a complex of about $15 \mathrm{~km}$ of galleries that are generally of large dimensions. They extend between the Vicdessos valley (Grotte de Niaux entrance at $672 \mathrm{~m}$ a.s.1., Grotte de Sabart at $559 \mathrm{~m}$ ) and the Ariège (Grotte de Lombrives, $605 \mathrm{~m}$ ). The modern valley floors are lower, betwen 480 and $520 \mathrm{~m}$ a.s.l. In hydrologic terms, the caves are abandoned, relict. The caves occur at two distinct levels approximately $50 \mathrm{~m}$ apart. They contain many important sedimentary deposits, detrital and chemical, whose study has permitted one of us (Sorriaux, 1982) to reconstruct their later history in relation to exterior morphologic and climatic events.

\section{Stratigraphy of the cave sediments}

As shown in Table I, the sediments can be divided into three distinct units, each composed of two different formations. Each unit is separated from the others by a clearly marked erosion surface; locally, the earlier deposits have been completely removed.

The basal formation in each unit is a suite of alluvial detrital deposits of external origin. The overlying formation is a suite of interior deposits, particularly of chemical precipitates. Each unit therefore represents a sequence where, first, the caves were active water channels (base levels of the cave entrances and exits) and, second, the caves became inactive (base levels of flow rose high above the caves, inundating them, or fell below them as they are today). 
Table I Stratigraphy of underground sediments in Niaux-Lombrives-Sabart system. N.W.S.: non working draining structure, w.S.: working structure.

\begin{tabular}{|c|c|c|c|}
\hline Unit & Formation & Name & Description \\
\hline \multirow[b]{2}{*}{3} & 6 & late deposits & $\begin{array}{l}\text { upper (elevation above } 540 \mathrm{~m} \text { a.s.l.): } \\
\text {-speleothems } \\
\text { - detrial carbonates } \\
\text {-solution residue } \\
\text { lower (elevation below } 540 \mathrm{~m} \text { a.s.l.): } \\
\text {-fine detrital sediments }\end{array}$ \\
\hline & 5 & $\begin{array}{l}\text { 'alluvial formation } \\
\text { of Niaux' }\end{array}$ & $\begin{array}{l}\text {-3rd step: internal sedimentation. N.W.S. } \\
\text {-2nd step: -upper (above } 645 \mathrm{~m} \text { a.s.1.) } \\
\text { N.W.S., alluvial sediment } \\
\text {-lower (below } 645 \mathrm{~m} \text { a.s.1.) } \\
\text { W.S., alluvial sediment } \\
\text {-lst step: W.S. everywhere, alluvial sediments. }\end{array}$ \\
\hline \multirow[b]{2}{*}{2} & 4 & 'upper calcite floor' & N.W.S., speleothems. \\
\hline & 3 & $\begin{array}{l}\text { 'Conglomerates of the } \\
\text { Galerie des Comtes } \\
\text { de Foix }\end{array}$ & Alluvial sediments with thin calcite floors. \\
\hline \multirow[t]{2}{*}{1} & 2 & Red formation & $\begin{array}{l}\text { Typical dryness formation } \\
2 \mathrm{c} \text { : 'calcite complexe' } \\
2 \mathrm{~b} / \mathrm{a} \text { : 'clay complexe' with ice calcite levels. }\end{array}$ \\
\hline & 1 & $\begin{array}{l}\text { 'Alluvial formation } \\
\text { of Lombrives' }\end{array}$ & $\begin{array}{l}\text { - Decanting sediments } \\
\text {-Alluvial sediments }\end{array}$ \\
\hline
\end{tabular}

\section{The problem of dating}

Although mapping and correlation underground, plus petrographic and sedimentological analyses in the laboratory, permit detailed reconstructions of the general evolution and functioning of the caves, they can neither establish the absolute ages of the events discerned nor, above all, determine what were the causes of the major and abrupt changes of base level. They do suggest, however, that the sands of Formations 3 and 5 (Table I) derive at least in part from a glacial environment, which is supported by accumulations of cryoclastic debris on top of them. In the past, the younger alluvial deposits in Grotte de Niaux have been related to the Quaternary glaciations, but without any kind of decisive proof. Exterior glacial and associated deposits in the valleys do not preserve any record of events older than the last (or Würm) glaciation (Taillefer 1982). It is quite clear that the multi-phase sequences in Niaux-Lombrives-Sabart must extend further back in time. For these reasons we have attempted systematic dating of the karst deposits.

\section{Uranium series methods and their reliability}

The detrital deposits cannot be dated. Only the chemical deposits (cave calcites) offer possibilities, by application of U-series disequilibrium methods $\left({ }^{230} \mathrm{Th} /{ }^{234} \mathrm{U}\right.$; Schwarcz 1978). As a consequence, only the upper parts of each depositional sequence in a unit can be dated.

The results are presented in Table II. Most of them are reliable. The $U$ concentrations of between 0.05 and $0.82 \mathrm{ppm}$ are adequate. Yields of $\mathrm{U}$ and $\mathrm{Th}$ during laboratory extraction processes are generally better than $10 \%$, and so are acceptable. Three samples (ND 10-1, ND 3-1 and LD 2-t) gave poor yields at first but replicate analyses of the former two produced acceptable results.

Samples ND 2-1, ND 17-b, LI 6-t and 7-t, and SD 1-b-1 had obviously suffered from leaching after deposition. This took the form of dissolution-recrystallisation sequences sometimes recognizable in their sections. It is the cause of ${ }^{230} \mathrm{Th} /{ }^{234} \mathrm{U}$ ratios much greater than 1.0 , i.e. $\mathrm{U}$ is preferentially extracted during the dissolution step. All these samples were from Formation 2 in 
Table II. Radiometric age data for Niaux-Lombrives-Sabart caves. For sample references, (1) and (2) are repeated analyses; $t$ is top and $b$, base of floor samples.

\begin{tabular}{|c|c|c|c|c|c|c|c|c|c|c|}
\hline \multirow{2}{*}{\multicolumn{2}{|c|}{$\begin{array}{l}\text { Sample } \\
\text { ref. }\end{array}$}} & \multirow[t]{2}{*}{$\mathrm{F}$} & \multirow[t]{2}{*}{ Uppm } & \multicolumn{2}{|c|}{ Yields $\%$} & \multirow[t]{2}{*}{${ }^{234} u /{ }^{238} U$} & \multirow{2}{*}{${ }^{230} \mathrm{Th} / /^{234} \mathrm{U}$} & \multirow{2}{*}{${ }^{230} \mathrm{Th} / /^{232} \mathrm{Th}$} & \multirow{2}{*}{$\begin{array}{c}\text { Non Corr. Age } \\
\text { ka } \quad \text { BP }\end{array}$} & \multirow{2}{*}{$\begin{array}{l}\text { Corr. Age } \\
\text { ka__ BP }\end{array}$} \\
\hline & & & & $U$ & Th & & & & & \\
\hline ND & $10(1)$ & 6 & 0,12 & 41,0 & 5,0 & $1,221 \div 0,065$ & $0,204 \div 0,048$ & $2,75 \pm 2,0$ & - & - \\
\hline ND & $10(2)$ & 6 & 0,11 & 58,9 & 33,9 & $1,179 \pm 0,044$ & $0,034 \pm 0,011$ & 1000 & 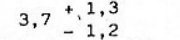 & $3,7+1,3$ \\
\hline ND & $18 \mathrm{t}$ & 6 & 0,24 & 7,2 & 34,2 & $1,582 \pm 0,137$ & $0,119 \pm 0,010$ & $2,19 \pm 0,2$ & $(13,6 \pm 1,2)$ & $4,5 \pm 2,2$ \\
\hline ND & $18 \mathrm{~b}$ & 6 & 0,24 & 30,9 & 48,8 & $1,327 \pm 0,030$ & $0,043 \pm 0,004$ & $64,0 \pm 23,0$ & $4,8 \pm 0,5$ & $4,8 \pm 0,5$ \\
\hline LD & 1 & 6 & 0,09 & 17,5 & 46,2 & $1,450 \pm 0,096$ & $0,110 \pm 0,013$ & $2,67 \pm 0,7$ & $12,6 \pm 1,5$ & $5,7 \pm 3,4$ \\
\hline LD & $2 t$ & 6 & 0,09 & 4,2 & 37,0 & $1,632 \pm 0,3$ & $0,234 \pm 0,03$ & $1,55 \pm 0,3$ & - & - \\
\hline LD & $2 b$ & 6 & 0,09 & 23,7 & 50,4 & $1,277 \pm 0,075$ & $0,098 \pm 0,011$ & $3,18 \pm 0,8$ & $11,2 \pm 1,3$ & $6,1 \pm 2,6$ \\
\hline SD & $2 b$ & 6 & 0,14 & 18,8 & 42,7 & $1,264 \pm 0,071$ & $0,102 \pm 0,011$ & $5,12 \pm 1,7$ & $11,7 \pm 1,3$ & $8,4 \pm 2,3$ \\
\hline ND & $1(1)$ & 6 & 0,23 & 60,8 & 71,0 & $1,163 \pm 0,046$ & $0,162 \pm 0,013$ & $30,5 \pm 52$ & $19,1 \pm 1,6$ & $19,1 \pm 1,6$ \\
\hline ND & $1(2)$ & 6 & 0,21 & 22,4 & 18,5 & $1,293 \pm 0,047$ & $0,168 \pm 0,016$ & $2,02 \pm 0,3$ & $19,9 \pm 2,1$ & $8,1 \pm 3,9$ \\
\hline ND & $8 t$ & 4 & 0,82 & 59,0 & 29,8 & $1,324 \pm 0,013$ & $0,586 \pm 0,010$ & $25,8 \pm 2,2$ & $91,4 \pm 2,4$ & $91,4 \pm 2,4$ \\
\hline ND & $8 b$ & 4 & 0,45 & 59,0 & 25,0 & $1,384 \pm 0,017$ & $0,878 \pm 0,018$ & $22,6 \pm 1,8$ & $\begin{array}{r}189,7^{+}+9,9 \\
-9,1\end{array}$ & $\begin{array}{r}185,2+10,4 \\
-\quad 9,6\end{array}$ \\
\hline ND & 14 & 4 & 0,11 & 24,5 & 67,0 & $1,209 \pm 0,079$ & $0,720 \pm 0,044$ & $11,3 \pm 2,2$ & $\begin{array}{r}130,6+16,0 \\
-14,0\end{array}$ & $\begin{array}{r}120,5+18,1 \\
-16,3\end{array}$ \\
\hline ND & $16 \mathrm{~b}$ & 4 & 0,20 & 25,5 & 43,3 & $1,387 \pm 0,046$ & $0,738 \pm 0,024$ & $17,0 \pm 1,8$ & $132,6+8,3$ & $126,0+9,0$ \\
\hline LI & $6 \mathrm{t}$ & 4 & 0,08 & 10,3 & 12,1 & $1,102 \pm 0,138$ & $1,333 \pm 0,147$ & $2,58 \pm 0,2$ & indet. 7,7 & Inde $\bar{t} \cdot{ }^{8,5}$ \\
\hline ND & $15 \mathrm{~b}$ & 3 & 0,21 & 21,7 & 31,3 & $1,068 \pm 0,049$ & $0,907 \pm 0,046$ & $6,49 \pm 0,6$ & $\begin{array}{r}240,9+54,4 \\
-36,5\end{array}$ & $\begin{array}{r}216,9+57,4 \\
-39,4\end{array}$ \\
\hline SD & I $\mathrm{t}$ & $2 c$ & 0,16 & 9,6 & 42,7 & $0,961 \pm 0,081$ & $0,833 \pm 0,064$ & $9,96 \pm 1,3$ & $\begin{array}{r}199,2 \pm 59,0 \\
-36,5\end{array}$ & $\begin{array}{r}186,8+60,7 \\
-39,5\end{array}$ \\
\hline ND & 4 & $2 \mathrm{c}$ & 0,63 & 36,6 & 36,6 & $0,965 \pm 0,015$ & $0,912 \pm 0,027$ & $8,68 \pm 0,3$ & $\begin{aligned} 277,1 & +48,6 \\
& -33,2\end{aligned}$ & $\begin{aligned} 257,0 & +49,3 \\
& -33,9\end{aligned}$ \\
\hline ND & $7 \mathrm{t}$ & $2 c$ & 0,08 & 54,3 & 42,4 & $1,091 \pm 0,062$ & $0,935 \pm 0,057$ & $25,1 \pm 8,6$ & $\begin{aligned} 265,2 & +94,5 \\
& -51,4\end{aligned}$ & $\begin{array}{r}265,2+94,5 \\
-51,4\end{array}$ \\
\hline SD & I b (1) & $2 c$ & 0,05 & 32,9 & 30,3 & $0,849 \pm 0,129$ & $1,618 \pm 0,274$ & $6,38 \pm 2,1$ & indet. & indet. \\
\hline SD & I b (2) ? & $2 c$ & 0,14 & 8,6 & 42,7 & $0,859 \pm 0,094$ & $1,073 \pm 0,107$ & $9,96 \pm 1,3$ & 350 & 350 \\
\hline ND & $7 \mathrm{~b}$ & $2 c$ & 0,14 & 68,0 & 77.7 & $1,120 \pm 0,036$ & $0,996 \pm 0,031$ & $7,40 \pm 0,4$ & 350 & $\begin{aligned} 331,0 & +29,1 \\
& -58,5\end{aligned}$ \\
\hline ND & $3(1)$ & $2 c$ & 0,16 & 12.1 & 4,7 & $1,043 \pm 0,059$ & $1,012 \pm 0,079$ & $\begin{array}{c}28,7+33,5 \\
-\end{array}$ & - & - \\
\hline ND & $3(2)$ & $2 \mathrm{c}$ & 0,16 & 56,7 & 74,2 & $1,031 \pm 0,034$ & $1,027 \pm 0,038$ & $41,1 \pm 13,6$ & 350 & 350 \\
\hline ND & 12 & $2 c$ & 0,08 & 28,8 & 15,8 & $1,160 \pm 0,063$ & $1,045 \pm 0,057$ & $25,6 \pm 9,0$ & 350 & 350 \\
\hline NI & $4 t$ & $2 \mathrm{c}$ & 0,23 & 27,2 & 36,1 & $0,958 \pm 0,035$ & $1,082 \pm 0,044$ & $9,46 \pm 0,8$ & 350 & 350 \\
\hline ND & 13 & $2 c$ & 0,13 & 32,0 & 17,4 & $1,031 \pm 0,052$ & $1,015 \pm 0,061$ & $55,2 \pm 41$ & 350 & 350 \\
\hline ND & $17 \mathrm{~b}$ & $2 c$ & 0,12 & 12,4 & 49,9 & $0,801 \pm 0,074$ & $1,264 \pm 0,115$ & $36,1 \pm 13,0$ & indet. & indet. \\
\hline ND & $2(1)$ & $2 \mathrm{~b}$ & 0,34 & 52.1 & 77,3 & $0,956 \pm 0,021$ & $1,181 \pm 0,033$ & $26,6 \pm 2,5$ & indet. & indet. \\
\hline ND & $2(2)$ & $2 \mathrm{~b}$ & 0,33 & 18,2 & 15,1 & $1,008 \pm 0,032$ & $0,955 \pm 0,036$ & $10,6 \pm 1,1$ & $\begin{aligned} 331,3 & +62,1 \\
& -61,0\end{aligned}$ & $\begin{aligned} 318,5 & +71,6 \\
& -62,5\end{aligned}$ \\
\hline L.I & $7 \mathrm{t}$ & $2 \mathrm{~b}$ & 0,19 & 12,4 & 26,4 & $0,975 \pm 0,058$ & $1,497 \pm 0,085$ & $13,7 \pm 1,6$ & indet. & indet.. \\
\hline NI & 5 & $2 \mathrm{~b}$ & 0.16 & 61.7 & 39,9 & $0,9 \% \pm 0,016$ & $1,028 \pm 0,021$ & $16,3 \pm 1,2$ & 350 & 350 \\
\hline
\end{tabular}

the first unit. This formation appears to have the most complex history.

One third of the measured samples contain little thorium of detrital origin, as indicated by ${ }^{230} \mathrm{Th} /{ }^{232} \mathrm{Th}$ ratios $\geq 25$. All other samples have some Th detrital contamination. Their calculated ages have been corrected as suggested by Schwarcz (1980). The correction factor presumes an initial ${ }^{230} \mathrm{Th} /{ }^{232} \mathrm{Th}$ ratio of 1.25 . Corrected ages are not as accurate as those calculated from samples low in ${ }^{232} \mathrm{Th}$.

\section{Results}

Four groupings of dates appear in Table II. Each of these is obtained from a well-defined formation. These are, from top to base:

Formation 6, which began to grow about $19 \mathrm{ka}$ B.P. and continues today. Concretions became much more abundant after $12 \mathrm{ka}$.

Formation 4, accumulated between $190 \mathrm{ka}$ and $90 \mathrm{ka}$. Flowstone ND 8 is the best example. There is a major hiatus in its growth between 175 


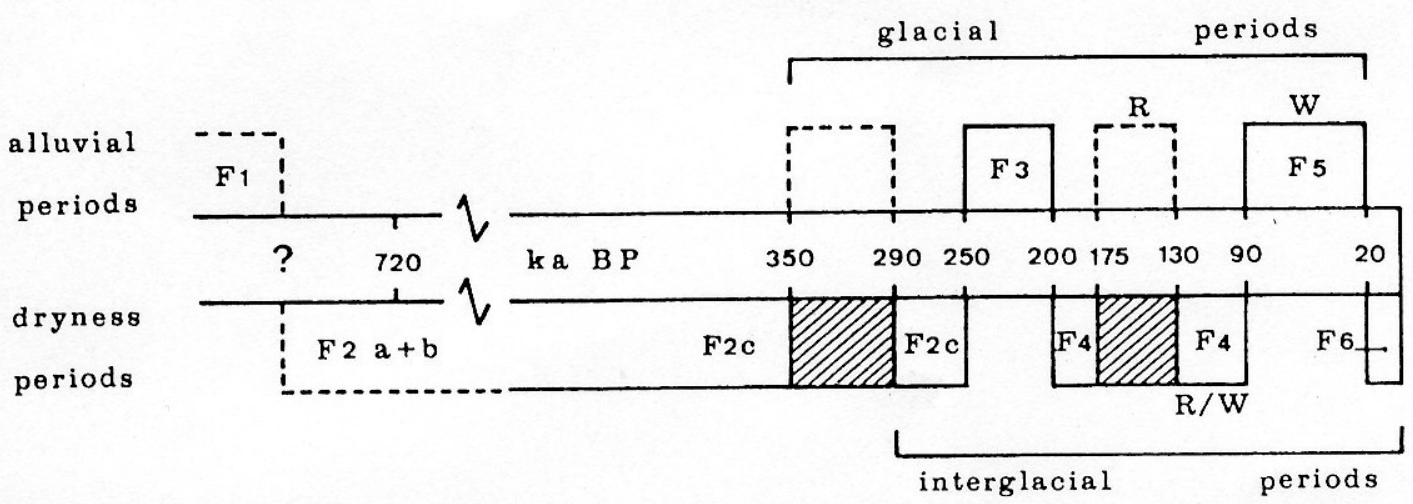

Fig. 1. Chronostratigraphy of pleistocene events deduced from dating of speleothems in Niaux system. R: Riss glaciation; W: Würm glaciation; R/W: Riss-Würm interglacial.

and 130 ka approximately.

Formation $2 c$, for which flowstone ND 7 is the best sample. It displays two phases of growth, the upper being between $\sim 280$ and $250 \mathrm{ka}$, and the lower being around or earlier than $350 \mathrm{ka}$. Once again, the two phases are separated by a clear hiatus in growth.

Formation $2 b$ is greater than $350 \mathrm{ka}$ in age. This is the limit of $U$ series methods. The carbonate layers often show evidence of re-solution, causing leaching of $U$ and unacceptable results (ND 2 and LI 7-b). First exploratory paleomagnetic measurements on the calcite yield a reversed polarity (F. Semah, personal communication). These suggest that at least a part of this formation is older than 720,000 y B.P., the date of the last reversal of the Earth's magnetic field. More precise studies need to be undertaken to confirm this result.

From these findings we can establish a chronology for some of the events which have contributed to the rejuvenation of the caves in the massif of Cap de la Lesse (Figure 1). Development of the two distinct levels of galleries (Niaux-upper Lombrives, Sabart-lower Lombrives) occurred before $720 \mathrm{ka}$. These were the two principal phases of karstification.

Deposition of Formation 1, which is in upper Lombrives and is the oldest surviving alluvial deposit, took place later. It may have followed soon after the opening of the lower level, or it may be much younger. It was succeeded by a long period when the caves were hydrologically inactive and calcites accumulated. This period commenced before 720 ka (Formations 2a and $2 b)$, and its end is represented by the complex of flowstones and stalagmites, Formation $2 \mathrm{c}$, which began before $350 \mathrm{ka}$ and ended about $250 \mathrm{ka}$. There is an important hiatus in growth between $\sim 350$ and $\sim 290 \mathrm{ka}$; at the sites that have been investigated there was no significant erosion or deposition during this interval.

The second alluvial phase (Formation 3) occurred between 250 and $200 \mathrm{ka}$, it was marked by at least one lengthy interruption in the river flow when calcite sample, ND 15-b, was laid down. The phase thus represents two abrupt, probably brief, rises of the base level of flow in the valleys. These we may correlate with glacier advances.

There was another period of no hydrologic activity between 200 and $90 \mathrm{ka}$. Cave calcites were laid down, with a major hiatus in their deposition between 175 and $130 \mathrm{ka}$ that, once again, is without any significant erosion or deposition of clastics. We may correlate this hiatus with marine isotope Stage 6 of Emiliani (1955), the penultimate glaciation. Finally, there was a last flooding of the caves at one or more times between 90 and $20 \mathrm{ka}$. This is clearly associated with the last (Würm) glaciation. It began with deposition of fluviatile sediments (Formation 5) and was succeeded by a complete inundation of the cave system. This inundation is correlated with glacier ice burial of the entire Cap de la Lesse massif during the earlier Würm that is described by Taillefer (1977). The postglacial period began in this region about $19 \mathrm{ka}$.

Study and dating of sediments in the NiauxLombrives-Sabart system shows that during the last 350,000 years there has been an alternation between cold periods marked either by hiatuses in speleothem growth or by reactivation of fossil 
stream passages (Formations 3 and 5) and warmer periods with calcite deposition (Formations $2 c, 4$ and 6). This alternation is well known and has been described in ocean floor deposits (Emiliani 1955; Van Donk 1976, etc.) and from speleothems in other karst regions (Harmon, Ford \& Schwarcz 1977). Although a sequence of several glaciations has been suspected from other evidence in southern France (Taillefer 1977) only the last, or Würm, glaciation can be demonstrated from surface deposits in the Pyrenees. The work that we have reported here is the first description of glacial sequence and deposits definitely older than the Würm glaciation in these mountains.

REACTIVATION D'UN PALEOKARST AU COURS DES GLACIATIONS QUATERNAIRES, D'APRES LES DONNES DE LA CHRONOLOGIE ABSOLUE. L'EXEMPLE DU SYSTEME DE NIAUX-LOMBRIVESSABART (PYRENEES ARIEGEOISES, FRANCE)

Situées à environ $150 \mathrm{~m}$ au-dessus du niveau de base actuel, les grottes de Niaux, Lombrives et Sabart représentent un ancien réseau de drainage qui a fonctionné entre les vallées du Vicdessos et de l'Ariège. Dans ces grottes, trois unités sédimentaires successives ont été étudiées en détail. Chaque unité est constituée de 2 parties. La partie inférieure est détritique, d'origine fluviatile; elle témoigne du fonctionnement hydrologique du réseau de conduit. La partie supériure de chaque unité est composée surtout de concrétionnements, et correspond à une période d'assèchement, lorsque le paléokarst évoluait au-dessus du niveau de base. Ces conditions sont semblables à l'environnement actuel des grottes.

Seules les concrétions carbonatées des parties supérieures de chaque unité ont été datées par la méthode Uranium-Ionium. Les dates, tirées de 27 échantillons, sont en bon accord avec les données d'Europe et d'Amérique du nord. Ainsi, les sédiments fluviatiles moyen (250 à $200 \mathrm{ka}$ ) et supérieur (90 à $20 \mathrm{ka}$ ) correspondent à des phases glaciaires majeures, qui ont réactivé le karst.

Deux autres évènements sont marqués seulement par une lacune des dépots carbonatés, le premier entre 350 et $290 \mathrm{ka}$. Le second entre 175 et $130 \mathrm{ka}$. Par comparaison avec les données d'autre régions, ces deux évènements sont reliés à des phases glaciaires de moindre importance dans cette région puisqu'il n'y a ni érosion, ni sédimentation détritique.

Les sédiments fluviatiles les plus anciens sont recouverts par des concrétions plus âgées que $350 \mathrm{ka}$ et, en partie, que 720 ka (d'après des données paléomagnétiques à confirmer); d'après leur sédimentologie, ils ne peuvent pas être rattachés à une phase glaciaire. Ils sont peut-être contemporains de la formation des grottes de cette région.

\section{References}

Emiliani, C. 1955. Pleistocene temperature. J. Geol., 63. 538578

Harmon, R. S., Ford. D. C. \& Schwarcz, H. P. 1977. Interglacial chronology of the Rocky and Mackenzie Mountains based on ${ }^{230} \mathrm{Th} /{ }^{234} \mathrm{U}$ dating of calcite speleothems. Can. J. Earth. Sci. 14(11). 2543-2552.

Schwarcz, H. P. 1980. Absolute age determination of archaeological sites by uranium series dating of travertines. Archaeometry, 22, 1. 3-24.

Sorriaux, P. 1982. Contribution à l'étude de la sédimentation en milieu karstique. Le système de Niaux-Lombrives-Sabart (Pyrénées ariègeoises). Thèse $3 \mathrm{e}$ cycle, Université de Toulouse, $255 \mathrm{p}$.

Taillefer, F. 1977. Le glacier de l'Ariège dans le bassin de Tarascon. Revue géog. Pyrénées et Sud-Ouest, 48. 269-286.

Taillefer, F. 1982. Sédiments des karsts et géomorphologie. Revue géog. Pyrénées et Sud-Ouest, 53. 433-477.

Van Donk, J. 1976. ${ }^{18} \mathrm{O}$ record of the Atlantic ocean for the entire Pleistocene epoch. Geol. Soc. America, 145: 147-163. 